Article

\title{
Plea for an Emic Approach Towards 'Ugly Movements': Lessons from the Divisions within the Italian Pro-Life Movement
}

\author{
Martina Avanza \\ Institut d'Etudes Politiques, Historiques et Internationales-CRAPUL, University of Lausanne, 1015 Lausanne, Switzerland; \\ E-Mail: martina.avanza@unil.ch
}

Submitted: 15 March 2018 | Accepted: 11 July 2018 | Published: 14 September 2018

\begin{abstract}
Studies of the pro-life movement have invariably been undertaken in relation to the pro-choice movement. The stress on comparison has tended to homogenize the two sides, thus understating their internal differences. This article extends beyond an analysis bounded by a movement-countermovement dichotomy. Based on ethnographic data and on the Italian case, it considers several questions that arise from revealing the intramovement divisions at various levels. First, there are tensions relating to the relationship between orthodoxy and institutionalized politics: how far, if at all, should there be doctrinal compromises in exchange for influence over public policy? Secondly, the conflicts over modes of action. In this respect, should protests be visible in public spaces, and if so how? These two issues govern the tense relationship between the Movimento per la Vita and more radical groups. Thirdly, the issue that divides the Movimento itself; the ongoing dialogue over the attitude to be taken towards contraception, and thus sexuality. At the heart of these intramovement struggles is the definition of what a 'real' pro-life movement is, and how a 'real' pro-life movement should mobilize. This article reveals a complex and highly fragmented image of the pro-life movement that, like every social movement of a certain size, is heterogeneous in its demographic composition, objectives and strategies. To show this complexity, the article adopts an emic approach that does not limit itself to a reading of conservative movements through the eyes of progressive movements.
\end{abstract}

\section{Keywords}

abortion; anti-feminism; countermovement; emic; ethnography; intramovement conflicts; Italy; pro-life; 'ugly movements'

\section{Issue}

This article is part of the issue "The Feminist Project under Threat in Europe", edited by Mieke Verloo (Radboud University, The Netherlands) and David Paternotte (Université Libre de Bruxelles, Belgium).

(C) 2018 by the author; licensee Cogitatio (Lisbon, Portugal). This article is licensed under a Creative Commons Attribution 4.0 International License (CC BY).

Know your enemy!

Come on!

-Rage Against the Machine

\section{Introduction}

This article forms part of a thematic issue which explores how and why the feminist project is under threat in Europe. There is of course no simple answer to this question as the various contributions clearly illustrate. This research will address one specific threat to the feminist project represented by organized social movements with an anti-feminist agenda. Drawing on a specific case study of the anti-abortion movement in Italy, it is argued that more attention needs to be paid to opponents of the feminist-project, and a reappraisal of the manner in which we study them is overdue. Social movement studies have addressed anti-feminist and more broadly 'conservative' movements mainly as countermovements: movements opposed to social change and to the progressive movements that fight for it. It is argued here that we should go beyond this perspective and proceed to study these groups as standalone subjects, rather than only in relation to the 'progressive' movements and the agenda that they oppose. The idea behind this is a simple one: 
we can only know what anti-feminism is if we are able to understand its worldview and read its variant strategies. Focusing only on a movement-countermovement dynamic limits a more nuanced understanding, thus restricting the capacity to respond to threats.

My fieldwork on the Italian pro-life movement raised questions over the nature of the extant literature. It was clear from the outset of the ethnography, that there was a striking level of conflict within the movement itself. On social networks, in interviews, and at events, what provoked the most heated debates were the positions of rival pro-life groups, rather than the real antagonists (the pro-choice movement). From the outset, this context guided the research to pay considerably more attention than I imagined to the internal divisions of the prolife movement-few traces of which were present in the existing literature.

To report on these divisions, an approach was adopted that considers 'conservative' movements in their own right; according to the priorities that make sense in their environment. This approach avoids homogenizing a movement that is in fact divided and diverse. It also allows the understanding of how these internal divisions shape the strategies the movement employs. The literature underlines the major role played by the conflicts between movements and countermovements, especially in the case of pro-choice versus prolife mobilizations in the US (Meyer \& Staggenborg, 1996, 2008; Rohlinger, 2002; Staggenborg, 1991). My data on the pro-life movement in Italy also shows the major role of conflicts, but specifically highlights the intramovement differences. Forty years since the legalization of abortion, the movement is now essentially shaped more by intramovement divisions, rather than by confrontation with the pro-choice movement. By revealing the significance of intramovement conflicts, the case study will also benefit future analyses of so-called 'ugly movements ${ }^{1}$, where such approaches have been seldom undertaken. Social movements scholars have tended not to study these groups because they find them ideologically unappealing, and when they have done, they observed them from the outside in, and in relation to the 'progressive' movements that they fight (pro-life/prochoice, anti-gay/LGBT). In such analyses a movement can appear to be markedly unified. However, as my evidence suggests, things are considerably more complicated when looked at on the inside. The argument maintained here is that emic perspectives are best served by an ethnographic non-comparative research design that goes beyond a simple juxtaposition of movement with countermovement.

After a critical review of the literature on movementcountermovement dynamics, particularly emphasizing the pro-choice/pro-life conflict, the article will consider the literature that defends an emic and ethnographic ap- proach toward 'distasteful social movements' (Esseveld \& Eyerman, 1992). It will then outline the methodology employed in the case study before presenting the three main conflicts that were revealed within the Italian pro-life movement. The lessons learned from these divisions are subsequently underlined, giving a more nuanced understanding of social movements that differs significantly from the canonical 'progressive' movements around which social movement theories are commonly built. The article ends with a plea for an emic approach to give a more revealing explanation of 'ugly movements'.

\section{Getting Beyond an Analysis in Terms of Movement-Countermovement}

In the literature on social movements the American pro-life movement has become the ideal-typical figure of a countermovement. This is because this movement reunites the two definitions that we can find in the literature.

The first definition is what Blais and Dupuis-Déri (2012) call mechanistic: a countermovement is one that arises and acts in response and opposition to an existing movement. According to this definition, a countermovement may be progressive or reactionary. What is important here, is to identify which movement initiates the cycle of contention (Lo, 1982; Zald \& Useem, 1987). Underlying the importance of the dynamic between two movements, this definition highlights the fact that both share the same object of concern and influence each other (Fetner, 2008; Meyer \& Staggenborg, 1996, 2008). The American pro-life movement perfectly illustrates this definition: it arose in reaction to the legalization of abortion in 1973 and, has hitherto been engaged in a movement-countermovement dynamic with the pro-choice movement.

The second definition, identified here as ideological, states that a countermovement is a movement that specifically opposes social change rather than another social movement (Blais \& Dupuis-Déri, 2012; Mottl, 1980; Zald, 1979). It is thus defined as necessarily reactionary. Even when the 'conservatives' first started to mobilize against gay marriage mobilization, they were still labeled as a countermovement, or, in order to reintroduce an historical timeline, an 'anticipatory countermovement' (Dorf \& Tarrow, 2014). Obviously, the antiabortion movement also fits this second definition. It has been this, the ideological definition, that has held sway in the literature.

The pro-life movement has mainly been studied in its opposition-influence relation to the pro-choice movement. The definitive book by Susan Staggenborg (1991) clearly showed how the dynamics of the movementcountermovement influenced the mobilization cycles and strategies of both camps. With regard to the

\footnotetext{
${ }^{1}$ Expression coined by Sidney Tarrow (1994). 'Ugly movements' and similar labels are indicated in quotations marks, like 'conservatives', because, following Polletta, who stresses 'there is nothing intrinsically awkward about any movement, group, or tactic. Awkwardness is in the eye of the beholder' (2006, p. 476), they seem to me more ideological then analytical.
} 
mobilization cycle, the victories of one camp can be transformed into a mobilizing effect for the losers, as was the case for the pro-life movement following the Roe v. Wade judgment. As for modes of action, it is impossible to understand why pro-choice feminists started lobbying-a practice distant from their political culture-unless the successes of pro-life lobbyists in the late 1970 s are considered. Relations between movement and countermovement were thus described as being similar to a ping-pong match in which each player has to react and respond to the shots of the other (Green, 1992), a war (Zald, 1979), or to 'a sometimes loosely coupled tango of mobilization and demobilization' (Zald \& Useem, 1987, p. 247).

These research designs clearly had benefits, but not without some notable blind spots. Whilst it allowed the dynamic of the mobilization constituted by the movement-countermovement interaction to be discerned, it had the disadvantage of essentially insisting on the differences between the two rival camps; a comparison that has tended to homogenize the two parties and underestimate the significance of internal differences that structure each social movement.

The trend towards homogenization and reification is stronger for the 'conservative' camp than it is for the 'progressive' one, where internal conflicts are better known (Bernstein \& Taylor, 2013; Bracke, 2014; Ghaziani, 2008; Hirsch \& Fox Keller, 1990; McCammon, Bergner, \& Arch, 2015; Taylor, 1998; Taylor \& Rupp, 1993; Whittier, 1995). As Ziad Munson has noted:

There is a tendency to try to boil social movements down to a single underlying idea or belief. This is especially true of movements with which one disagrees: it is easier to dismiss an opposing viewpoint by reducing it to a sound bite or a simple (and ugly) message. Until now, the pro-life movement has been examined in this manner. (2008, p. 153)

Poulson, Caswell and Gray call for wariness in such a situation: "We think this "difference" between researcher and the subject of inquiry should make researchers act with particular care when they characterize the participants and nature of these movements' (2014, p. 240). It is this problem that the article seeks to overcome.

\section{Studying the 'Unlovable Groups'² from the Inside}

Studies of social movements have predominantly focused on western liberal movements rather than their 'conservative' opposites; consequently, 'conservative' movements have been largely neglected by scholars. According to Jasper:

One pattern seems to hold up over the last fifty years: former activists go to grad school and begin to write about the movements that energized them. This was once the New Left or civil rights, it is more recently the antinuclear, animal rights, LGBTQ, and other movements. (2012, p. 3)

The deficit of scholarship covering 'conservative' movements is thus related to the fact that liberal-minded scholars might be less inclined to study right-wing movements (Poulson, Caswell, \& Gray, 2014). This could also explain that when they do study 'conservatives', social movements scholars tend do this from a distance: through newspaper data, police sources, and official documents.

This is true (with some exceptions discussed below) for the literature on the pro-life movement. In this instance the social and ideological distance that separates progressive scholars from the movement is reinforced by a methodological approach that tends to seize the movement from the outside through a discourse analysis of official documents, sometimes alongside interviews-especially with leaders or focus groups. In a best-case scenario, these approaches can only take intramovement divisions into account in terms of frames (Ferree, Gamson, Gerhards, \& Rucht, 2002; Trumpy, 2014). However, as Munson has shown, and is indeed confirmed by my own data, 'ideas about action-what people actually do-turn out to be more consequential in the pro-life movement than the underlying basis for that action' (2008, p. 155). Yet, to grasp what it is that 'people actually do' demands being with them and watching them doing it. An ethnographic approach facilitates the considering of internal differences and the means assigned to these by the actors. Such an approach has been used in several studies of the far right, and in particular in the ground-breaking research projects by Kathleen Blee (2002) on women in Hate Groups: ethnography allows note to be taken of the 'surprising diversity' of these groups and their members 'a point often missed because of the tendency to emphasize their similarities' (Blee, 2002, p. 4). More recently, Arlie Russel Hochschild, after realizing that she did not know any member of the Tea Party (like I did not know any pro-life activist before my fieldwork), decided to get out of her 'political bubble' and spend five years doing ethnographic research in Louisiana with Tea Party enthusiasts, which she claims is the only way to try to 'see reality through their eyes' (2016, p. 5).

Regarding the literature on abortion, Faye Ginsburg (1989) wrote a beautiful book following an ethnographic study about the abortion conflict in Fargo. However, in comparing pro-life and pro-choice, she did not question the assumption that the pro-life movement was marked by internal heterogeneity. Ziad Munson (2008), who used qualitative (but not ethnographic) methods, is, to my knowledge, the only social movement scholar who adopted a specifically internalist perspective (Goodwin, 2006) toward the American pro-life movement by giving intramovement divisions, seen through the eyes of the

\footnotetext{
2 The expression "unlovable groups" is from Nigel Fielding, a scholar of the British National Front (1981, p. 7).
} 
people, a central importance. His work will be discussed extensively throughout the article.

In the Italian case, the only author working on the pro-life-movement is an anthropologist using ethnographic methods, who was interested in women's subjectivity in the abortion conflict (Mattalucci, 2012). This anthropological perspective has the clear advantage of taking the actors point of view into account but does not concern itself with issues related to theories of social movements. The remaining literature mostly deals with the centrality of the Church's role in morality politics and its influence in legal governance. With a few exceptions that have studied ecclesial movements (Faggioli, 2008; Marzano, 2012), the role of catholic inspired movements is seldom considered-the pro-life movement is thus severely understudied and merits detailed consideration.

Following the theoretical lead of Munson on the importance of internal divisions, and the methodological lead of ethnographic studies toward 'distasteful movements', an emic approach is defended here. It is argued that such an approach is best served by ethnographic study methods and a non-comparative research design to analyze 'repugnant others' (Harding, 1991) for themselves and from the inside. In other words, an approach that pays 'meticulous attention...to discourses and, more broadly, to the representations of actors' in order to 'take account of the indigenous point of view' (De Sardan, 1998, p. 159) is necessary, when the indigenous point of view is so profoundly different from that of the researcher, a strong risk of caricaturing and misinterpreting the people in the study is likely to be present.

\section{Data and Methodology}

The evidence presented here is based upon ethnographic research on the Italian pro-life movement. During the first stage of the fieldwork (February-July 2013) I was able to verify the feasibility of the research, define the boundaries of the pro-life movement, and identify the internal conflicts between the different organizations. This first stage of full time fieldwork was about gaining access and mapping the pro-life arena. During the second stage (2014-2015 academic year, half-time fieldwork), I concentrated on the main pro-life movement, the Movimento per la Vita (MpV) (the only one having a nationally-based constituency and chapters) and even more on its pregnancy crisis centers (Centri di Aiuto alla Vita, CAV). I was able to gain access to two of these centers, where I observed how pro-life activists deal with pregnant women. I was also able to observe local, regional and national meetings of the Movimento per la Vita, discovering how it works from the inside. During the third stage (2015-2016 academic year), the fieldwork continued at a less intense pace. I attended national meetings and conferences, including the MpV Papal Audience, but did not take part in the everyday life of the movement. In addition to participant observation, which provided my primary data, I also conducted thirty in-depth life-story interviews with male and female prolife activists in different organizations and at different levels of responsibility.

I had already worked ethnographically on a movement with which I profoundly disagree (Avanza, 2008), and as a feminist scholar I expected that it would be hard for me to spend time within the movement. To be sure, there were occasions especially while carrying out participant observation within the most radical groups that were difficult. For instance, praying in front of a hospital where abortions are performed was emotionally challenging. But several elements made the field less hard then I anticipated. One of them was the internal diversity of the movement, which meant I could find some people that were easier to spend time with than others-an experience that prompted me to take the internal diversity of the movement more seriously.

People knew that the movement was being subjected to research; notetaking was visibly carried out and interviews were recorded openly and with consent. I kept my personal opinions to myself; however, since I was taking part in conferences, marches, prayers and volunteering in pregnancy crisis centers, most activists assumed that I was sympathetic (even if I never said so) which made the fieldwork easier and served to deepen my access. This moral ambiguity is somehow inherent to the study of groups with which the ethnographer has an 'awkward relationship' (Snow, 2006).

This is an inductive research. I did not anticipate that the focus would direct itself to the intramovement conflicts, because I had no idea they existed. Obviously, I had done some reading before the fieldwork, but the reality that I discovered was, for the most part, not consistent with the literature. Indeed, the lack of research on the Italian pro-life movement contributed to the fact that I had no precise hypothesis. But this was also an epistemological choice: refusing to see 'conservatives' through the eyes of 'progressive' canonical social movements also meant giving the fieldwork a chance to generate the hypothesis. Since it is a field driven research, and not a theory driven one (Lichterman, 2002), the following will reveal the major intramovement divisions as they emerged from the field to connect each of them to the literature.

\section{Division No. 1: To Bear Witness or to Do Politics? About the Role Played by Religion in Activism}

The first and most important division that structures the Italian pro-life movement is that between pragmatism and idealism. It raises the fundamental question of how far, if at all, one is prepared to compromise on the principle that drives their involvement (being against all abortions), with the prospect of achieving qualified public policy results (e.g., stopping some abortions)? Or, does compromising any principles amount to compromising oneself and betraying pro-life activism? This division has structured the movement ever since its inception. 
In Italy, Catholics communities had endured legalization of abortion via the parliamentary route in 1978 (law number 194). However, faced with the referendum proposed by the Radical Party in a bid to repeal the most restrictive articles of the 194 law, they decided to react. They also organized a repeal referendum, but their goal was to make the law more restrictive (Calloni, 2001; Sciré, 2008). This was the origin of the first split within the movement. On one side, the budding MpV with its close ties to the Church supported a solution referred to as 'minimal', in which abortion would be allowed, but only where the mother's life was in danger. On the other, those communities close to the Church's anti-conciliar factions advocated the solution referred to as 'maximal': a total ban on abortion. Because the Constitutional Court upheld the 'maximal' solution as unconstitutional, only the MpV proposal was put to the vote in 1981 . However, only $32 \%$ of voters were in favor of it. Some proponents of the 'maximal' solution refused to support the MpV proposal in the name of the moral impossibility of voting for anything other than complete repeal.

Conflict between pragmatists and purists was played out within the MpV once again in 2004. This time it revolved around Law Number 40, concerned with medically assisted procreation and stem cell research. Pro-life activists, in accordance with the Church position (Ozzano \& Giorgi, 2016; Scalon, 2005), opposed in vitro fertilization claiming it necessarily means embryos would be destroyed. Both the MpV and the Italian Church did however decide to mobilize to get a law as close to their principles as possible (Frisina, Garelli, Pace, \& Scalon, 2015). Their lobbying achieved its goal. Article 2 of the law specified that one must respect all the subjects involved, including il concepito (the one that has been conceived), thus recognizing the embryo as a subject (Hanafin, 2007; Marchesi, 2013). The MpV also claimed other aspects of the law as positive results of its political action: the ban on producing more than three embryos; the obligation to implant all embryos produced at once; the ban on freezing embryos; and the bans on heterologous fertilization and on pre-implantation diagnosis ${ }^{3}$. But for MpV's more conservative members this was an intolerable compromise of principles. Once the law was approved, in February 2004, this minority left the MpV to establish the Comitato Verità e Vita. Mario Palmaro (1968-2014), a former vice-president of the $\mathrm{MpV}$, and a charismatic figure of the movement, led this conservative minority that gave birth to the Comitato. When interviewed (June 2013) he explained to me that a pro-life movement couldn't be in the 'grey zone' or defend a 'line of compromise' like he thought the $\mathrm{MpV}$ was doing. On the contrary it needed to stick with what he called a 'pro-life orthodoxy'. A pro-life movement, according to him, needs to be 'in the battle order' and be able to 'say what we need to say heeding no one'. The 2004 spilt initiated by Palmaro brought an end to the MpV's quasi-monopoly of the pro-life cause, which has since been defied by a growing number of radical groups that accuse it of compromising principles (see Appendix).

This split between pragmatism and absolutism is not limited to this case study. It is the main, and often the only, trait of division underlined by the literature on antiabortion movements. Building on Munson's findings, this case study explains this division and bring new elements to the discussion.

The American movement, divided ever since the 1970s over the inclusion of the exception clause (when the mother's life is threatened), found itself facing a similar dilemma between political effectiveness and the primacy of principles in attempting to reverse Roe v. Wade (Rohlinger, 2015). It was around this issue that a minority left the interfaith and pragmatic National Right to Life Committee (NRLC), founding the rival organization, the American Life League (ALL) in 1979. ALL explicitly defined itself as Catholic, leading Rohlinger and Quadagno (2009) to consider this conflict to be faithbased in origin. Without denying the significance of competition mechanisms between closely related faiths, the Italian case shows that the fault line between pragmatists and purists reaches well beyond faith-based differences. Here, we are not up against differing beliefs, because everyone at $\mathrm{MpV}$ is catholic and agrees that life begins at fertilization and that IVF techniques are 'antilife'. This was reiterated by Palmaro during our interview (June 2013): 'the issue is not the ideas defended by the Mpv'. For him the problem is related to 'the language', 'the style' and the 'flavor' of the movement. Consequently, there is a profound difference in definition of what a pro-life movement should be. Ought it be a matter of knowing what the horizon of aspiration is for such a movement: terrestrial or celestial? Is it all about launching into political battle to get results, albeit imperfect ones? Or, is it a matter of keeping 'a clear conscience towards God and towards men' as the Church catechism teaches? ${ }^{4}$ I argue that the response depends less on faith-based belonging (Catholic/Evangelical) and more on the role that is given to religion in activism.

The MpV defines itself as a secular movement that hopes to achieve tangible results in terms of public policy. In the MpV 2015 general assembly (Rome, 14 March), the newly elected President, Gian Luigi Gigli (a doctor and a parliamentarian) was very clear when he said that he wanted to 'reinforce the link with the scientific, legal and political circles' because otherwise 'our testimony won't translate into action' (field notes). In contrast, the radicals are more interested in bearing witness than doing politics. Palmaro maintained that the movement needs to 'keep a strong degree of dissonance'

\footnotetext{
${ }^{3}$ Almost all these bans have been progressively dismantled through court orders in the following years, including those of the European Court of Human Rights (Ozzano \& Giorgi, 2016). In the eyes of the radicals, this dismantling of the 40 law amounts to additional proof of the futility of the compromise strategy adopted by the MpV.

${ }^{4}$ http://www.vatican.va/archive/ccc_css/archive/catechism/p3s2c2a8.htm
} 
to preserve it's 'capacity to provide a testimony' (interview June 2013). Logically, the radicals address Catholics and the Church more than they do parliament and nonbelievers (especially since the arrival of Pope Francis, considered too moderate). Where they have a political network, this tends to come from groups of the catholic far right, like Forza Nuova ${ }^{5}$, which are excluded from exercising power.

Therefore, the case study presented here sheds new light on the place of religion in pro-life and other 'ugly movements' considered to be religious based. Many have held out religion as the key explanatory variable in understanding the pro-life movement. Kerry Jacoby (1998) for example, sees pro-life activism as more a religious movement than a social or political one, Munson however demonstrated that the religious picture of the movement...is complicated by division among activists over precisely what role faith should play in activism' (2008, p. 8). The data here shows, contra Jacoby, that even within a catholic-only movement, the attitude toward religion is not a variable that defines the movement from the outside, but a divisive one that is critically discussed within. This should encourage social movement scholars working on 'ugly movements' labelled as religious to take more seriously actors' reflexivity on this subject.

\section{Division No. 2: How to Fight. When Intramovement Conflicts Shape Repertoire of Tactics}

According to Munson (2008), the pro-life movement in the United States is structured as a set of organizations and activists with a universally held goal of ending all abortions, but one that is fragmented into four mutually exclusive movement streams: a political stream which focuses on legislation; a direct action stream which focuses on street protest; an individual outreach stream which focuses on individual women and their pregnancies; and a public outreach stream, which emphasizes education and broad societal awareness of the abortion issue. In Italy, the direction of campaign strategies is also a divisive issue-the movement's organizational structure, however, is very different.

The MpV developed in two distinct areas linked within a federal structure. One acts as a political and cultural body which acts as both political lobbyists (a political stream) and an agent for the distribution of a 'culture for life' (a public outreach stream). The other is situated in the care sector, located within more than 300 Pregnancy Crisis Centers managed by the MpV and intended to dissuade pregnant women from aborting by offering them help (individual outreach stream). In short, the $\mathrm{MpV}$ gathers to its bosom three of the four ways of struggling described by Munson. The only one not found at the MpV is direct action. It is therefore not surprising that it is this way of struggling that has mainly been de- veloped by the radical groups. Using the example of the main type of direct action in the Italian case, the March for Life, I will show how intramovement conflicts shape the repertoire of tactics. The literature stresses the importance of movement-countermovement dynamics in setting each movement's tactical agenda. In this view 'interactions with opponents...lead to adjustments and innovations in movement strategies' (Meyer \& Staggenborg, 2008, p. 211). However, what emerged from my data was the evidence that the interactions producing strategic innovation (the March) were not the ones between movement-countermovement, but the ones between different factions within the movement.

In its early stages, the MpV was considered a reactionary, misogynist movement, led by fundamentalists. Since then, the organization has gone to great lengths to earn itself a moderate image. The MpV now claims to be a 'for' movement (for life) rather than an 'against' movement (against abortion). This means that the $\mathrm{MpV}$ is no longer officially in favor of penalization of abortion, making it a borderline case in the international panorama and causing it to no longer be considered pro-life by the radical groups militating for abolition of Law 194 . This search for a moderated image partly explains why the $\mathrm{MpV}$ refuses to engage in direct action, even when nonviolent. The movement's composition adds social context to the mix: lawyers, doctors, teachers and housewives, all Catholic, of the upper-middle classes and full of a certain respectability that is expressed in moderated forms of self-expression and an unwillingness to expose themselves in the public space. The MpV thus privileges discretion, whether on the ground at its Pregnancy Crisis Centers or in its lobbying action, between 'properly brought up' people in the distinguished ambience of governmental or ecclesiastical palaces. Despite modes of public action being common in many countries, it is understandable why the MpV has never promoted a March for Life in Italy.

The radical groups saw the march as an unguarded opening and seized the opportunity to take ownership of this mode of action. In 2011 they organized the first march in the small town of Desenzano, promoted by two associations. The first, Famiglia Domani (see Appendix), was founded in 1990 by the Marquis Luigi Coda Nunziante, who was close to the neo-fascist groups of Rome as well as to the most conservative Church factions. The other was the Movimento Europeo per la Difesa della Vita e della Dignità Umana (MEDV). Although an empty box was presided over by a personality who was significant in this community: the author of numerous pro-life books, Francesco Agnoli, son and nephew of two of the promoters of the 1981 'maximal' referendum and fierce critic of the MpV. The 2011 march may have gone almost unnoticed, but in 2012, when it was held in Rome for the first time, the MpV started to have a problem with it. In 2013, an organizational committee for the march was es-

\footnotetext{
${ }^{5}$ Forza Nuova (FN) is a neo-fascist movement founded in 1997. It became a party in 2000. The first point of the FN program is the abrogation of the 194 law legalizing abortion. The party scores, which is small minority, are around $0,2 / 0,5 \%$.
} 
tablished. It included several radical pro-life groups, but not the MpV. The march, with its 'for life without compromise' slogan, was organized in open opposition to the $\mathrm{MpV}$ moderation. Not only the radicals took the streets, but they marched together with extreme-right groups like Forza Nuova (when the MpV want nothing to do with extremist groups), held bloody photos of aborted fetuses (which the MpV strictly prohibit) and showed explicit catholic symbols (which the Mpv never does in public events). Valerio, the organizer of the bus that took me from Brescia to Rome for the 2013 March, explained to me during the trip that 'the people of life' that attend the March 'is sick of the MpV sluggishness' and therefore 'decided to bypass-it' (field notes).

Following a stormy discussion at its general assembly of 16-17 March 2013, which I attended, the MpV decided to leave each local group of its federation free to take part in the march without officially supporting or opposing it. At the 2014 general assembly, which I also attended (Rome 22-23 March), the line taken was the same. The president (Carlo Casini) reported that the 'hard line' the organizers of the march took was 'suicidal' and defended the realism of the MpV 'of course I am against the 194 law! But we have to find a strategic line' (field notes). The disagreement sharpened after I left the field and ended in 2018, when the MpV President (Gianluigi Gigli) formally prohibited (in a letter that was leaked to the press) the local movements and CAV to take part in the March 'to avoid any possible confusion between our organization and these extremist and badly traditionalist groups'. ${ }^{6}$

The MpV's opposition to both direct action and having a visible presence in the public arena, is explained by both strategic issues (not seeming like anti-woman religious fundamentalists), and issues around the social respectability of $\mathrm{MpV}$ activists, who refuse to 'make a spectacle of themselves'. What the MpV dislikes about the march is precisely what attracts the radical groups: being visible in public space, telling the 'whole truth' about abortion even if it is not nice to see (e.g., photos of aborted fetuses), not having to apologize for thinking that faith should come first (the conspicuousness of religious symbols). Therefore, if the radicals decided to organize the march, it is not because they are forced to follow the pro-choice movement into the arena of street protest (as it would be understood in a movementcountermovement analysis), it is because it was an open defiance of the moderate $\mathrm{MpV}$, allowing them to advance their vision of what a pro-life movement should be.

of course, other elements must be taken into consideration, not least the international circulation of repertoire of actions (Broqua, Fillieule, \& Roca, 2016). But the influence of the movement on its countermovement was not a factor, for the simple reason that the feminist movement is not active in Italy nowadays about the abortion issue. To support this claim, I was only once confronted with feminists during the fieldwork: I was in Milano with a radical group praying in front of a hospital where abortions are carried out and there was a feminist group protesting against the action. During the interviews, feminists are central in the discourse of the older activists when they talk about the beginning of the $M p V$ and the abrogative referendum campaign (1978-1981). Giusi, for instance (80 when I met her in April 2013), told me that she received a life threat during the campaign and that they had to hide the signatures they had collected for the referendum, because they were afraid that the feminists would destroy them. During those first years of highintensity conflict, the movement-countermovement dynamics had clearly played a role, including when it came to define the repertoire of actions. Giusi, for instance, told me that she organized a 'silent march' against abortion in Bergamo (her hometown) at the beginning of the 1980s: 'I said to the others: we won't scream. The feminists scream. We will remain silent'. But feminists never appear in the interviews with younger activists, or even with the older ones when they talk about the present day. However, rival pro-life groups often appear in the interviews as the political other from which one needs to distance his or herself when deciding how to mobilize.

The role of internal dynamics illustrated here shows how the strategic choices of other 'ugly movements' can be better explained and understood. If their choices are only considered as a response to the progressive agenda there is a high likelihood of misunderstanding the dynamics of these movements; 'ugly movements' can develop their own agendas, even more so when the conflict extends over a long period of time.

\section{Division No. 3: The Pro-Life Sex War7. Intramovement Conflicts and Status Politics}

Joseph Gusfield has shown how the Temperance movement was driven by status struggles:

Precisely because drinking and nondrinking have been ways to identify the members of a subculture, drinking and abstinence became symbols of social status, identifying social levels of the society whose styles of life separated them culturally. (1963, p. 4)

By substituting the practice of drinking with the practice of premarital sex, and even considering the context of marriage as one where sexuality is not governed by the standard of 'natural methods' of controlling fertility, this quotation could easily be used to define the $\mathrm{MpV}$. The only exception being that this status, used to define the 'us' of the movement, is no longer agreed upon nowadays.

\footnotetext{
${ }_{6}^{6}$ http://www.marcotosatti.com/2018/01/05/il-movimento-per-la-vita-intima-di-non-partecipare-a-una-futura-eventuale-marcia-per-la-vita-a-roma-enon-stiamo-scherzando

${ }^{7}$ I purposely employ the formula 'sex war', used first to designate intra-feminist controversies at the beginning of the 80 's about pornography, prostitution and sadomasochism (Ferguson, 1984). It is a way of saying that controversies around sexual issues also occur in 'conservative' movements.
} 
The MpV's official position on contraception is ambiguous. The movement claims to be secular, yet it accurately reproduces the Church position on the question as it is found in the 1968 Humane Vitae encyclical, and in the post-synod document on the family, Amoris Laetitia, in 2016. These documents, despite recognizing that marital sexuality cannot be reduced to reproduction, reaffirmed that contraception remained forbidden; only natural methods of controlling fertility were deemed to be acceptable for the exercise of 'responsible parenthood'. These methods allow births to be spaced out, but, because they cannot guarantee that there will be no pregnancy, their use implies that couples remain 'open to life'. Most couples and women I met at the MpV extol the virtues of these methods, highlighting not only their effectiveness (all their pregnancies were apparently wanted), but also their benefits for the couple. At the 2014 national meeting (7-9 November in Pescara), for instance, I had a long talk with a couple in their late 30s who uses natural methods. They acknowledge that it has been difficult: it took almost three years for them to learn correctly how to go about it (because of her irregular menstrual cycle and ovarian cysts) and they had to endure 'never ending periods of chastity'. But they still think that 'it was worth it' because now they had a 'better communication' within the marriage, 'a greater intimacy' and their sexuality was not 'mediated by latex or hormones'. After many years of marriage, their 'desire is still alive' because of the waiting periods, whereas the pill, due to the hormones, 'kills female desire'.

At an organizational level, the $\mathrm{MpV}$ also promotes these methods and opposes contraception. The homepage of the $\mathrm{MpV}$ website for its young members features a list of ' 5 uncomfortable questions'. The first of these is 'Contraception: a non-alternative to abortion'. It states that contraception, "because of the cavalier attitude to sex it encourages', results in an increase in unwanted pregnancies and thus in abortions. ${ }^{8}$

This discourse in favor of natural methods is still dominant today within the $\mathrm{MpV}$, although not unanimously. According to some activists, under the leadership of a gynecologist member of MpV's executive committee, this 'sexophobic' attitude could distance the organization from a potential audience of young people, who are thought of as being opposed to abortion, but not non-procreative and premarital sexual activity. Between the pro-life pro-sex, and the more conservative wing of the movement, which accepts only natural methods, a real sex war is now being waged. The pro-sex group calls partisans of natural methods the 'banda del muco' ('mucus band') because observation of vaginal mucus is one of the techniques used in natural methods to find out whether a woman is on a fertile day. The defenders of natural methods consider that the pro-sex group has lost sight of their struggle, which is not confined to the abortion issue, but is also about which model of so- ciety, especially with regard to sexual behaviors, is desirable. The issue is particularly sensitive when it comes to questions around the CAV (pregnancy crisis centers): for example, should the volunteers of the pregnancy crisis centers talk about contraception or just about natural methods? At the MpV 2014 National meeting (7-9 November in Pescara) there was a workshop called 'educate to life' to address this issue. Some participants, all women, some of them teachers of natural methods, argued that the movement can't talk about contraception because it means separating sex and reproduction. Others agreed in theory, but they thought that the movement needed to be realistic. The gynecologist leader of the pro-sex faction was furious 'do you think that we can avoid teen pregnancies with the Billings methods?'. A counselor in the CAV said, 'What do I have to do when a woman I convinced to keep the baby asks me what to do in order to avoid another unwanted pregnancy?'. According to a woman who is an OBG and a volunteer in a CAV 'our priority has to be to protect the unborn' (meaning even if we have to say to a woman to take the pill). But another woman volunteer, who is a retired social worker, had an opposing view. For her, contraception will bring more abortions 'the connection has been proven'. Another woman answered, rolling her eyes, 'sometimes I think you live in Alice in Wonderland'. The tension was palpable. The chair of the workshop in his conclusion tried to find a compromise. He argued that 'we don't have to give up on our values' but also that 'we have to consider the kind of society that we are living in'. Therefore 'we need to promote natural methods' but also to acknowledge that they are 'not for everybody': 'the movement can't confine itself to natural methods if we want to stay in touch with reality'. The women who spoke up in favor of the exclusivity of natural methods were not satisfied at all with this conclusion and left the room without even saying goodbye (field notes).

The conflict is thus concerned as much with what the movement must publicly justify, but also how far the definition of legitimate sexuality can be stretched for a prolife activist. The issue is conflictual because it affects the definition of a militant 'us'. As Joshua Gamson has shown, internal debates aimed at defining the 'legitimate us' are gendered in social movements, even more so in sexual ones. In the gay movement, 'The debate over group boundaries was...closely tied to disputes over how one properly does "masculine" as a gay man' (1997, p. 182). In the case of the MpV, the issue at stake is the model of sexual respectability. Hitherto, embodied by the use of natural methods, this model of respectability is no longer unanimously agreed upon. As Lilian Mathieu stresses:

The positions or values defended by a moral crusade never form a stable or predefined given, but are very likely to evolve over time..., as well as on account of variations in internal power dynamics. $(2005$, p. 4)

\footnotetext{
$\overline{8}$ http://www.prolife.it/category/5-domande-scomode
} 
This describes what is happening at the MpV; a 'modernizing' minority are trying to push the boundary of what constitutes this 'us'.

Whilst this division is central to the MpV, any mention of the sex war appears absent in the literature. The centrality of the subject in my case study is definitely linked to dominance of Catholicism within the movement. However, revealing this division is something only made possible by the methodologies used, and the analytical strategies employed. Organizations are generally reluctant to expose their divisions to the light of day, especially when they deal with sensitive subjects, like the sex-life of the activists. Consequently, the immersion into the pro-life milieu was the only way to ensure reliable access to these debates.

Highlighting the sex war in the MpV is a way of challenging the literature on status politics and life-style movements that has commonly been used to analyze countermovements (Gusfield, 1963; Moen, 1988; Page \& Celland, 1978) and in particular pro-life activism (Luker, 1984; Staggenborg, 1987). In this literature, a countermovement is the expression of a threatened group who wants to defend its lifestyle (Mottl, 1980). This literature has produced important results but runs the risk of reifying the movement by depicting its members as more homogeneous than they really are. The case study presented here strongly suggests that lifestyle controversies do not occur only between a movement and its countermovement, but also within a movement.

\section{Conclusion}

What is a 'real' pro-life movement? Is it religious or secular? Should it be exemplary (even if nothing is gained) or effective (at the price of compromising on principles)? How should it conduct the fight: in the public arena, or in the palace corridors? To whom should it address itself? To married Catholics attached to their own sexual respectability, or also to young people engaging in non-marital sexual activity and who are not necessarily Catholic? These are the questions currently stirring up the Italian pro-life movement. They are important questions, ones that will reflect upon in defining their strategies in terms of its mode of influence and mode of action. For example, do they try to implement pro-life public policies or renounce them to stay 'pure'? Should they lobby, or partake in direct action? These considerations also define the audience that they seek to reach; ought they be Catholic or not necessarily so, abstinent or not especially so?

To get to grips with them, the dominant perspective in the literature, that of considering movementcountermovement as the key explanatory variable, does not possess all the tools necessary to explain variant strategies or modes of action. It is not a matter of contesting this approach as such-just its omnipresence. As David Meyer and Susan Staggenborg themselves stress (1996), the approach they suggest is particularly well suited when movement and countermovement engage in a continuous interaction with/against the other. This often is the case in moments of high-intensity conflict, as was the case in Italy between the legalization of abortion in 1978 and the repeal referendum suggested by the MpV in 1981-a period that saw feminists and pro-life activists in open and direct conflict. Within this context of breaking legislative news, the movementcountermovement framing may prove relevant in shedding light on the mobilization dynamic. Today, however, the pro-life movement rarely confronts the feminist movement, which is not very active on abortion issues. In a phase of structuring the mobilization over the long term, and without legislative news, it seems to me that the emic non-comparative approach used in this article is more appropriate.

Every activist I encountered during my fieldwork profoundly believed that life begins at conception and that consequently abortion is ending a life. Despite this, activists do not agree on how to end abortion and thus on what the nature of a pro-life movement should be. There are two very good reasons why feminist and social movements scholars should care about these internal struggles. First, while the literature tends to present them as monolithic, 'conservatives' are no less complex and diverse than 'progressives'. Secondly, without taking intramovement conflicts seriously there is a risk that our interpretations will be erroneous and our findings spurious. In this case, it would have been easy to reduce the movement dynamics to a religious explanation if looked at from the outside, while the approach adopted here revealed the religious nature of the movement to be internally contested. It would have also been unlikely that tactical choices were shown to be (at least in part) the product of internal competition and not designed as a response to an enemy movement. Furthermore, there would have been a salient risk of considering the movement as one that mobilizes to defend a lifestyle, when observed closely, the lifestyle itself is contested within the movement. These points will prove useful beyond this case study and will give a more nuanced set of tools to scholars of those 'ugly movements', which tend to be reduced to either a mere religious phenomenon, a reaction to a 'progressive' social movement, or as a lifestyle constituency.

Using an emic approach is also a way of saying that 'ugly movements' are just movements. The fact that we (progressive feminist social movement scholars) find their message unappealing is not a sound scientific reason to create a category of movement that is not analytical. The same is true for the category of 'countermovement' when it is used, as it is most of the times, not in a mechanical but in an ideological way. If 'distasteful' social movements and countermovements are just movements, we should study them for themselves, not only in relation to the 'progressive' movements and agenda that they oppose. 


\section{Acknowledgments}

The first stage of the fieldwork for this paper was financially supported by the Tremplin funding of the Office of Equal Opportunity at the University of Lausanne. Thank you for your help! In developing the ideas presented here I would like to acknowledge the helpful input I have received from Christophe Broqua and Olivier Fillieule. I would also like to offer the warmest gratitude to David Paternotte and Mieke Verloo for the opportunity to contribute to this thematic issue and for the confidence they have shown in me.

\section{Conflict of Interests}

The author declares no conflict of interests.

\section{References}

Avanza, M. (2008). Comment faire de l'ethnographie quand on n'aime pas ses indigènes? Une enquête au sein d'un mouvement xénophobe [How to do ethnography when you dislike your indigenous? A fieldwork within a xenophobic movement]. In D. Fassin \& A. Bensa (Eds.), Les politiques de l'enquête [The politics of fieldwork] (pp. 41-58). Paris: La Découverte.

Bernstein, M., \& Taylor, V. (Eds.). (2013). The marrying kind. Debating same-sex marriage within the lesbian and gay movement. Minneapolis, MN: University of Minnesota Press.

Blais, M., \& Dupuis-Déri, F. (2012). Masculinism and the antifeminist countermovement. Social Movement Studies, 11(1), 21-39.

Blee, K. (2002). Inside organized racism. Women in the hate movement. Berkeley, CA: University of California Press.

Bracke, M. A. (2014). Women and the reinvention of the political. Feminism in Italy, 1968-1983. New York and London: Routledge.

Broqua, C., Fillieule, O., \& Roca i Escoda, M. (2016). Sur le façonnement international des causes liées à la sexualité [On the international shaping of sexual causes]. Critique Internationale, 70, 9-19.

Calloni, M. (2001). Debates and controversies on abortion in Italy. In D. McBride Stetson (Ed.), Abortion politics, women movements, and the democratic state: $A$ comparative study of state feminism (pp. 181-203). Oxford: Oxford University Press.

De Sardan, J-P. O. (1998). Emique [Emic]. L'Homme, 38(147), 151-166.

Dorf, M. C., \& Tarrow, S. (2014). Strange bedfellows: How an anticipatory countermovement brought same-sex marriage into the public arena. Law \& Social Inquiry, 39(2), 449-473.

Esseveld, J., \& Eyerman, R. (1992). Which side are you on? Reflections on methodological issues in the study of 'Distasteful' social movements. In M. Diani \& R. Eyerman (Eds.), Studying collective action (pp.
217-237). London: Sage.

Faggioli, M. (2008). Breve storia dei movimenti cattolici [Short story of Catholic movements]. Roma: Carrocci.

Ferguson, A. (1984). Sex war: The debate between radical and libertarian feminists. Signs, 10(1), 106-112.

Ferree, M. M., Gamson, W. A., Gerhards, J., \& Rucht, D. (2002). Shaping abortion discourse. Democracy and the public sphere in Germany and the United States. Cambridge: Cambridge University Press.

Fetner, T. (2008). How the religious right shaped lesbian and gay activism. Minneapolis, MN: University of Minnesota Press.

Fielding, N. (1981). The National Front. London: Routledge.

Frisina, A., Garelli, F., Pace, E., \& Scalon, R. (2015). The Italian Catholic Church and the artificial-insemination referendum. In K. Dobbelaere \& A. Pérez-Agote (Eds.), The intimate polity and the catholic church (pp. 93-123). Leuven: Leuven University Press.

Gamson, J. (1997). Messages of exclusion. Gender, movements and symbolic boundaries. Gender and Society, 11(5), 178-199.

Ghaziani, A. (2008). The dividends of dissent: How conflict and culture work in lesbian and gay marches in Washington. Chicago, IL: University of Chicago Press.

Ginsburg, F. (1989). Contested lives. The abortion debate in an American community. Berkeley, CA: University of California Press.

Goodwin, M. (2006). The rise and faults of the internalist perspective in extreme right studies. Representation, 42(4), 347-464.

Green, E. C. (1992). Those opposed: Southern antisuffragism, 1890-1920 (Unpublished Doctoral Dissertation). Tulane University, New Orleans, USA.

Gusfield, J. R. (1963). Symbolic crusade. Status politics and the American Temperance movement. Champaign, IL: University of Illinois Press.

Hanafin, P. (2007). Conceiving life. Reproductive politics and law in contemporary Italy. Andershot-Burlington: Ashgate.

Harding, S. (1991). Representing fundamentalism: The problem of the repugnant cultural other. Social Research, 58, 373-393.

Hirsch, M., \& Fox Keller, E. (Eds). (1990). Conflicts in feminism. New York, NY: Routledge.

Hochschild, A. (2016). Strangers in their own land. Anger and mourning in the American right. A journey to the heart of our political divide. New York and London: The New Press.

Jasper, J. (2012). Where did capitalism go? Critical Mass Bulletin, 37, 2-3.

Jacoby, K. N. (1998). Souls, bodies, spirits: The drive to abolish abortion since 1973. Westport, CT: Praeger.

Lichterman, P. (2002). Seeing structure happen: Theorydriven participant observation. In B. Klandermans \& S. Staggenborg (Eds.), Methods of social movement research (pp. 118-145). Minneapolis and London: University of Minnesota Press. 
Lo, C. (1982). Countermovements and conservative movements in the contemporary U.S. Annual Review of Sociology, 8, 107-134.

Luker, K. (1984). Abortion and the politics of motherhood. Berkeley, CA: University of California Press.

Marchesi, M. (2013). Between the law and bioethics: Placing the unborn in contemporary Italy. Academic Journal of Interdisciplinary Studies, 3, 284-290.

Marzano, M. (2012). Quel che resta dei cattolici. Inchiesta sulla crisi della Chiesa in Italia [The remaining Catholics. Investigation on the Church-crisis in Italy]. Milano: Feltrinelli.

Mathieu, L. (2005). Repères pour une sociologie des croisades morales [Benchmarks for sociology of the moral crusades]. Déviance et société, 29(1), 3-12.

Mattalucci, C. (2012). Pro-life activism, abortion and subjectivity before birth: Discursive practice and anthropological perspectives. Mediterranean Journal of Social Sciences, 3(10), 109-118.

Meyer, D. S., \& Staggenborg, S. (1996). Movements, countermovements, and the structure of political opportunity. American Journal of Sociology, 101(6), 1628-1660.

Meyer, D. S., \& Staggenborg, S. (2008). Opposing movement strategies in US abortion politics research. Social Movements, Conflicts and Change, 28, 207-238.

McCammon, H., Bergner, E., \& Arch, S. (2015). 'Are you one of those women?' Within-movement conflict, radical flank effect, and social movement political outcomes. Mobilization, 20(2), 157-178.

Moen, M. C. (1988). Status politics and the political agenda of the Christian right. The Sociological Quarterly, 29(3), 429-437.

Mottl, T. L. (1980). The analysis of 'countermovements'. Social Problems, 27(5), 620-635.

Munson, Z. (2008). The making of pro-life activists. Chicago and London: The University of Chicago Press.

Ozzano, L., \& Giorgi, A. (2016). European culture wars and the Italian case. London and New York: Routledge.

Page, A. L., \& Celland, D. A. (1978). The Kanawha county textbook controversy: A study of the politics of life style concern. Social Forces, 57, 265-281.

Polletta, F. (2006). Mobilization forum: Awkward movements. Mobilization, 11(4), 475-478.

Poulson, S. C., Casewell, C. P., \& Gray, L. R. (2014). Isomorphism, institutional parochialism, and the study of social movements. Social Movement Studies, 13(2), 222-242.

Rohlinger, D. A. (2002). Framing the abortion debate: Organizational resources, media strategies, and movement-countermovement dynamics. Sociological Quarterly, 43(4), 479-507.
Rohlinger, D. A. (2015). Abortion politics, mass media, and social movements in America. Cambridge: Cambridge University Press.

Rohlinger, D. A., \& Quadagno, J. (2009). Framing faith: Explaining cooperation and conflict in the US conservative Christian political movement. Social Movement Studies, 8(4), 341-358.

Scalon, R. (2005). Bioetica e sfera pubblica. Un'analisi sociologica del dibattito su fecondazione assistita e eutanasia [Bioethics and Public Sphere. A sociological analysis of the debate on IVF techniques and euthanasia]. Milano: Franco Angeli.

Sciré, G. (2008). L'aborto in Italia. Storia di una legge [Abortion in Italy. History of a law]. Milano: Mondadori.

Snow, D. (2006). Are there really awkward movements or only awkward research relationship? Mobilization, 11(4), 495-498.

Staggenborg, S. (1987). Life-style preferences and social movement recruitment: Illustration from the abortion conflict. Social Science Quarterly, 68(4), 779-797.

Staggenborg, S. (1991). The pro-choice movement: Organization and activism in the abortion conflict. Oxford: Oxford University Press.

Tarrow, S. (1994). Power in movement. Social movements and contentious politics. Cambridge: Cambridge University Press.

Taylor, J. (1998). Feminist tactics and friendly fire in the Irish women's movement. Gender \& Society, 12(6), 674-691.

Taylor, V., \& Rupp, J. (1993). Women's culture and lesbian feminist activism: A reconsideration of cultural feminism. Signs: Journal of Women in Culture and Society, 19, 33-61.

Trumpy, A. (2014). Women vs. fetus: Frame transformation and intramovement dynamics in the pro-life movement. Sociological Spectrum, 34, 163-184.

Whittier, N. (1995). Feminist generations: The persistence of the radical women's movement. Philadelphia, PA: Temple University Press.

Zald, M. (1979). Macro issues in the theory of social movements; SMO interaction, the role of countermovements and cross-national determinants of the social movement sector (Working Paper No. 204). Ann Arbor, MI: Centre for Research on Social Organization.

Zald, M., \& Useem, B. (1987). Movement and countermovement interaction: Mobilization, tactics, and state involvement. In N. Z. Mayer \& J. D. McCarthy (Eds.), Social movements in an organizational society (pp. 247-271). New Brunswick: Transaction Books. 


\section{About the Author}

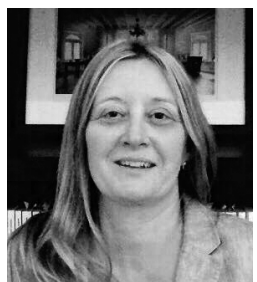

Martina Avanza is Senior Lecturer in Political Sociology at the University of Lausanne where she heads the Research Centre on Political Action (CRAPUL). Her research interests focus on political activism, especially conservative and right-wing activism that she studies using ethnographic methods and a gendered perspective. Her latest research is about the pro-life movement in Italy. She previously worked on the far-right Lega Nord party in Italy. 


\section{Appendix}

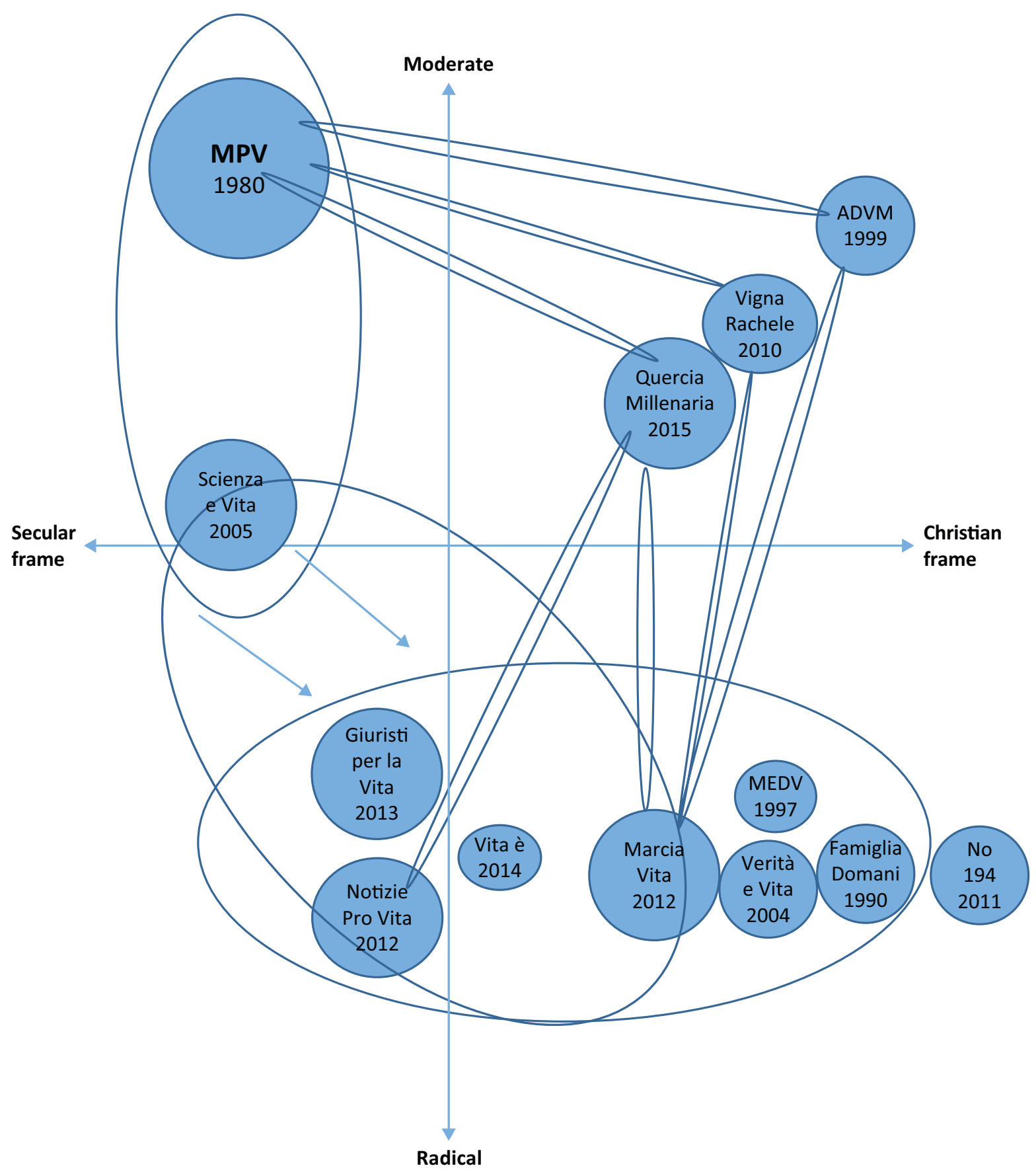

Figure 1. Mapping the pro-life arena.

The organizations (presented in chronological order and only the groups that were not detailed in the article are described here):

- Movimento per la Vita (MpV) [Movement for Life], 15,000 volunteers.

- Famiglia Domani [Family Tomorrow].

- Movimento Europeo per la Difesa della Vita e della Dignità Umana (MEDV) [European Movement for the Defense of Life and Human Dignity].

- Associazione Difendere la Vita con Maria (ADVM) [Association for the Defense of Life with Mary] is devoted to the burials of 'abortion remains'. This is the only pro-life association under the leadership of a priest.

- Verità e Vita [Truth and Life].

- Quercia Millenaria [Millennial Oak] offers couples who do not wish to abort a 'non-viable'fetus the option of continuing the pregnancy to full term. 
- Scienza e Vita [Science and Life]. Founded at the initiative of MpV, the association is essentially made up of doctors, and is intended to defend pro-life positions from a scientific, and thus secular, point of view. This group is very active; it organizes conferences and publishes a journal that is highly respected within the milieu.

- Vigna di Rachele [Rachel's Vine] organizes retreats for women (and sometimes couples) who have aborted or experienced a miscarriage. The goal is to 'heal' them of the 'post-abortion traumatism'.

- No. 194. The group name references law number 194, which in 1978 legalized abortion in Italy. The association aims to collect the 500,000 signatures necessary to initiate a referendum on a partial repeal of the law (unless the mother's life is in danger). This goal is regarded as totally unrealistic, even by the most radical groups. In addition, the association organizes prayers in front of hospitals in which abortions are carried out, a mode of action imported from the United States, and generally frowned upon in Italy. Both of its action pathways (the referendum bid and the public prayers), as well as the ostentatious behavior of its most visible members (who walk around with huge crosses bearing life-size, bloody images of 12-week fetuses) make No. 194 the most marginalized association in the pro-life arena.

- Marcia per la Vita [March for Life].

- Notizie Pro Vita [Pro-Life News] combines a website and a printed pro-life journal. It is highly active, organizing conferences, petitions, and email bombing campaigns aimed at elected representatives. The group is very close to neo-fascist party Forza Nuova.

- Giuristi per la Vita [Lawyers for Life] models itself on equivalent American associations. The association offers the services of a task force of legal experts, who work free of charge in defense of pro-life activists who are 'persecuted'. They also draw up texts for the use of pro-life elected representatives.

- Vita é [Life is] is an attempt to confederate the various radical pro-life associations to rival the MpV. The association is not very active. Among its founders are the leaders of Scienza e Vita, Notizie, Pro Vita, Giuristi per la vita and the March for Life committee.

For reasons of legibility, only single-issue groups are included in this graphic representation of the pro-life arena. Many other organizations, particularly those linked to Catholic 'associationism' (such as the organization of Catholic doctors) or movements of the Church (such as the Neocatechumenal Way) are part of this arena, but abortion is not their key concern. This is also true of a small number of openly anti-abortion political actors, such as the neo-fascist party Forza Nuova. The pro-life organizations I consider to be single-issue groups may also work on other themes, but abortion remains their core target.

\section{The axes:}

The vertical axis structures the pro-life arena by the degree of radicalism or moderation of the various groups. Radicalism is measured at once in terms of pro-life orthodoxy (with positions going from the non-abolitionist $\mathrm{MpV}$ to the radical groups intolerant of every exception clause, even where the mother's survival is in question), as well as modes of action. In this way, the No 194 group, which does tolerate exception clauses, has been placed at the same level of radicalism as Verità $e$ Vita, which does not, because of the way they behave in the public space.

The horizontal axis structures the pro-life arena by the degree of religiosity: more or less secularized. All pro-life groups are populated by Catholic activists, though some think that this dimension concerns the activists' private lives, others that it also defines the group's political action. In this case, prayer is an integral part of the group's mode of action. This is the case, for example, of the No 194 association or of ADVM.

\section{Links between organizations:}

The ellipses group those organizations that are close to, and collaborate with, one another. These collaborations are objectifiable through observation of speakers at the conferences organized by the various groups.

The wider the ellipses and the more they enclose the organizations, the stronger the links are. The narrower they are, the more episodic the links.

Three major poles emerge: the moderate, secular pole constituted by the $\mathrm{MpV}$; the radical pole, which offers a frame that is mainly, though not exclusively, Christian; the 'charitable' action pole, comprising the associations that take care of burying 'unborn children', supporting couples whose unborn child is not viable, 'healing' women who have aborted of their 'traumatism'. These associations, which are considered proof of 'human charity' maintain relations with both of the other poles. The radical pole and the MpV do not maintain any relations, and most often engage in head-on collision. The Scienza e Vita association, which was born out of an MpV imitative in 2004, has since moved closer to the radical pole, but while maintaining relations with the $\mathrm{MpV}$. The oblique arrows on the table indicate this slide.

Within the radical pole, individuals having responsibilities often hold multiple positions. This has the effect of multiplying the organizations, giving and impression of vitality, even though a relatively low number of individuals is concerned. The links between the groups of the radical pole are thus very close, with the notable exception of the No 194 association. 